\title{
Multi-Component Statistical Research in the area of Half-Hard Cast Iron Roll Manufacturing
}

\section{Imre Kiss}

University Politehnica Timișoara, Faculty of Engineering Hunedoara

Department of Engineering \& Management

5, Revolutiei, Hunedoara, Romania

e-mail: imre.kiss@ fih.upt.ro

Abstract: The current analysis is based on the concept that the proper quality of a particular type of alloy, such as half-hard cast irons and their properties, are determined by chemical composition and a proper melting and alloying processing, as well as, a special nodulizing treatment, assuring the graphite's nodular form. This analysis follows several key aspects of the manufacturing of half-hard cast iron rolls (also called "ductile iron rolls"), using the multivariate statistical research used as modelling approach upon the industrial data. In this sense, several results of a complex study on the half-hard cast iron rolls are presented, regarding the cumulative influences of several chemical components of the half-hard cast iron (Phosphorus, Sulphur and Magnesium), upon the Hardness, which is the common method of testing rolls, for the quality and predicted wear properties. The performed research herein has generated a number of multi-component regression equations and correlation coefficients, determined to the $3^{\text {rd }}$ and $4^{\text {th }}$ dimension spaces. Also generated are several regression surfaces and correlative level curves, which define proper technological areas. For the multiple regression equations and for the graphical addenda the Matlab software was used.

Keywords: cast iron rolls manufacturing; hardness; Phosphorus; Sulphur; Magnesium; multivariate regression analysis; regression equation; correlation charts

\section{Introduction}

In grey cast iron, graphite is present in the form of flakes [1-8]. Each of these graphite flakes under the concentrated action of an important effort, can cause the formation of cracks. In cast iron with spheroidal (nodular) graphite, known as ductile cast iron, graphite is no longer arranged in these flakes, but crystallizes in a spherical form [1-8]. Graphite in this form has a much smaller weakening effect on the matrix than the dispersed graphite flakes, in grey irons [1-8]. 
Ductile iron is not a single material, but is part of a group of materials that can be produced with a wide range of properties by controlling their microstructure. The common defining characteristic of this group of materials is the shape of graphite, namely nodular (or spheroidal). In nodular graphite irons free graphite is present as spheres or nodules in the as-cast condition [1-4]. The spherical structure of graphite (Figure 1) improves the quality of the cast irons, affecting increased hardness, reliability, supporting significant loads. Nodular irons therefore have considerably higher strength, ductility, and impact values than grey irons [1-8]. Ductile irons determine its properties by ferrite or perlite bases with the presence of nodular graphite inclusions. By close control of melting practice nodular irons can be produced in the as-cast condition over a wide range of section thicknesses with any required matrix structure from fully ferritic to fully pearlitic [1-4].

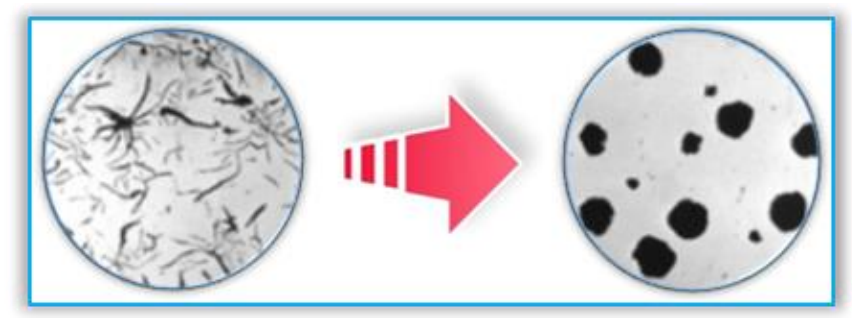

Figure 1

The most favorable form of graphite (minimum effect of loads' concentration)

The formation of nodules is carried out by adding nodulizing elements, Magnesium (0.04-0.12\%) most of the time and, less often today, Cerium [1-8]. Magnesium may be added directly to the ladle as Nickel-Magnesium, NickelSilicon-Magnesium or Iron-Silicon-Magnesium alloy [1-8].

Phosphorus and Sulphur contents should be as low as possible, as Phosphorus strongly decreases the plasticity and tenacity of the cast irons, and the Sulphur forms compound with the Magnesium (i.e. MgS). Thus contributes to the increase of the nodulizing elements consumption and to the impurification of the cast irons with sulphides [1-8].

Thus, the most important peculiarities of the chemical composition of nodular graphite formations are:

- High Carbon and Silicon content

- Low Phosphorus and Sulphur content

- Proper addition of nodulizing agent (i.e. Magnesium), which ensures the nodularization of graphite

Therefore, quality assurance is limited to good control of the process of elaboration/nodularization of irons [1-8]. It is very important that all elements are in a good correlation, as that ensures the desired quality. 
Rolls (Figure 2) - the main and very costly consumables in a rolling mill - are the tools of the rolling trade and the way they are used to execute their duty of deforming steel, in many cases largely determined by the roll's designer [9-16]. They are used in the rolling mill equipment and their performance depend on many factors which include the used materials and the loads to which they are subjected to during technological service [9-16]. The accuracy and speed of working and the roll's life are all related to its peculiar design and choice of materials, which implies a good working knowledge of both the used materials and the loads to which they will be subjected during service [9-16].

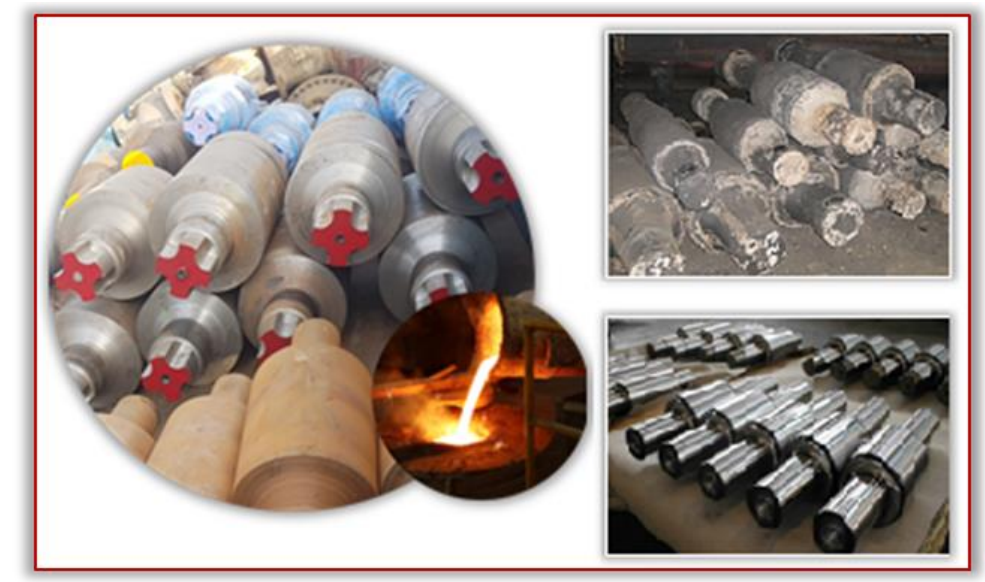

Figure 2

The Half-Hard Cast Iron Rolls - As-casting and mechanically processed condition [15] [16]

\section{Area of Research}

The static-cast nodular iron rolls (Figure 3 and Figure 4) are structurally characterized by the nodular shaped graphite in the microstructure, this feature being essential to the quality and consistency of ductile iron [15] [16]. Ductile rolls are structurally made up of cementite, matrix, and nodular graphite, the free carbon taking the shape of nodules, thereby, eliminating the notch effect of flake graphite and improving the mechanical properties of the cast iron rolls [9-24].

Ductile iron (usually hypereutectic) is produced by "in-ladle treatment" with adding Magnesium immediately prior to pouring castings, followed by inoculation in much the same way as for the production of gray cast iron. Cerium and Magnesium additions both produce nodular structures, but the latter has been found to be more adaptable and economical [1-4] [15] [16]. Both elements are desulphurizers and nodule formation is not possible until the Sulphur content has been lowered to about $0.02 \%$ [5-8] [15] [16]. 
It is necessary that the Sulphur content be kept $<0.01 \%$ for successful treatment, because of the affinity of Sulphur for Magnesium (forming $\mathrm{Mg} 2 \mathrm{~S}$ ), thus removing elemental Magnesium from the melt [5-8]. Finally, the nodular irons are inoculated with $0.4-0.8 \%$ Ferro-Silicon after nodulizing to refine the structure and minimize chilling [5-8] [15] [16].

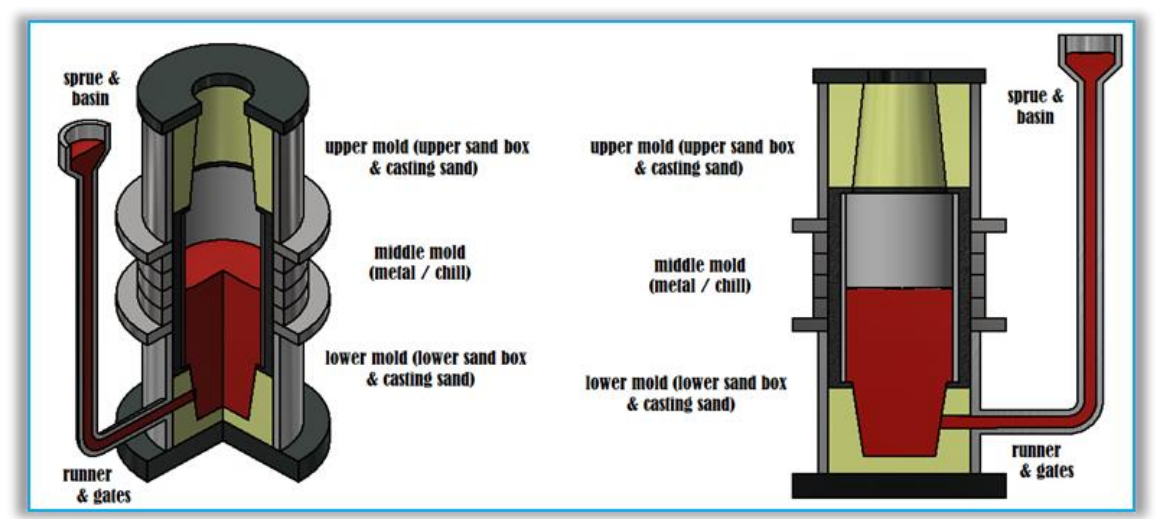

Figure 3

The Half-Hard Cast Iron Rolls - The static-cast process [15] [16]

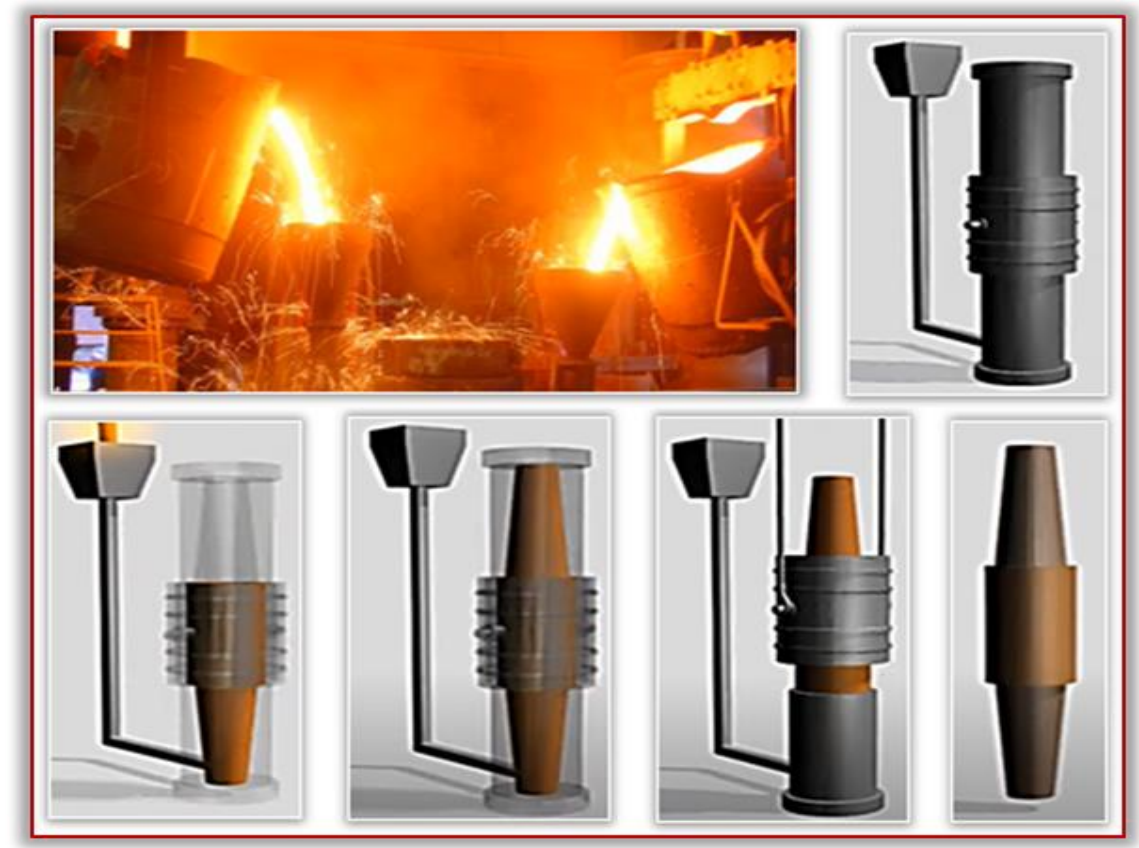

Figure 4

The Half-Hard Cast Iron Rolls - The casting \& operational phases [15] [16] 
The recommendations for the increase of the duration of exploitation and remove of the damages through the accidental rupture of rolls from the stands of lamination, the attenuation of rolls thermal fatigue, the avoiding of thermal shocks caused damages and their rational exploitation are actuality issues that must be continuously researched [9-24]. In this trend is situated the research of the castiron rolls (Figure 5) [15-24]. The quality of rolls is determined through hardness and through wear resistance, last index having a special importance for all modern rolling mills [9-24]. The presents of graphite in working surface (body of rolls) assures the friction coefficient necessary to obtain quality laminate [15-24].

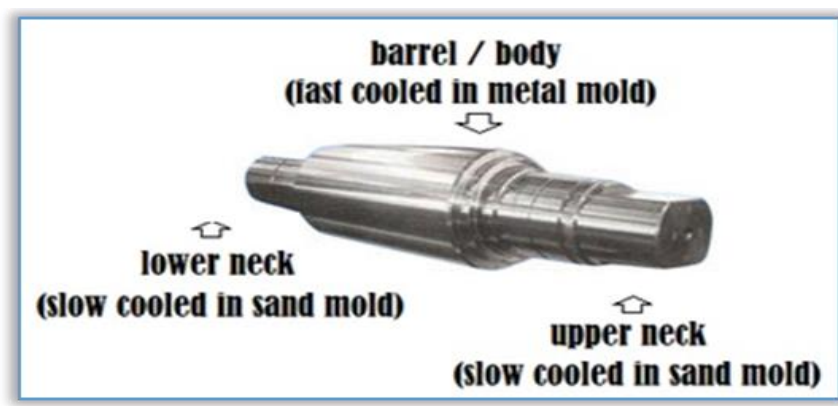

Figure 5

The Half-Hard Cast Iron Rolls [15] [16]

The rolls must present high hardness at the body of rolls and lower in the core and the neck's, adequate with mechanical resistance and in the high work temperature. If in the body, the hardness is guaranteed by the quantities of cementite in the structure of irons, the core of rolls must content graphite, to assure this property [9-24]. The research includes half-hard cast rolls, from nodular graphite irons, with the half-hard body of 40-150 mm depth [15] [16] [25]. The macrostructure is not imposed (except for the nodular graphite irons, where a spherical shape of the graphite is required), conditioned by the adequate quantities of cementite in the body and graphite in the core and on the necks [9-24]. Thus, the optimal additions in these elements can be determined to assure the proper hardness (Table 1 and Table 2).

Table 1

The Recommended Chemical Composition of the Half-hard Cast Iron Rolls [25]

\begin{tabular}{|c|c|c|c|c|c|c|c|c|}
\hline \multicolumn{9}{|c|}{ Chemical Composition, (\%) } \\
\hline $\begin{array}{l}\circlearrowright \\
\tilde{\Xi} \\
\vdots \\
\vdots \\
\tilde{U}\end{array}$ & $\begin{array}{l}\overline{i n} \\
\overline{0} \\
0 \\
\vdots \\
\overline{0}\end{array}$ & 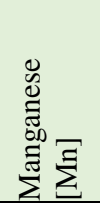 & 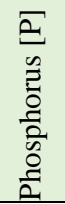 & $\begin{array}{l}\sqrt{2} \\
\vdots \\
\vdots \\
\frac{1}{n} \\
\text { in }\end{array}$ & $\begin{array}{l}\bar{Z} \\
\bar{\Xi} \\
\frac{y}{0} \\
\bar{z}\end{array}$ & 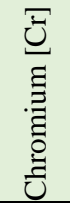 & 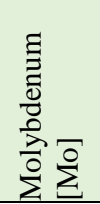 & 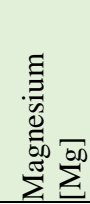 \\
\hline $3.0-3.5$ & $1.2-2.5$ & $0.1-0.7$ & $\begin{array}{l}\max \\
0.15\end{array}$ & $\begin{array}{l}\max \\
0.02\end{array}$ & $1.5-2.5$ & $\begin{array}{l}\max \\
0.8\end{array}$ & $0.3-0.5$ & $\begin{array}{l}0.02- \\
0.04\end{array}$ \\
\hline
\end{tabular}


This study analyses iron rolls cast in the static procedure, in combined forms (iron chill, for the barrel and molding sand, for the necks of the rolls) [15-24]. The research included 108 rolls from the half-hard class -0 and 1 hardness class, 219-347 Brinell units on body (working surface) and 195-271 Brinell units in core and on the necks of rolls (Table 3) [15] [16] [25].

Table 2

The Recommended Hardness of the Half-hard Cast Iron Rolls [25]

\begin{tabular}{|l|l|l|}
\hline Class of & \multicolumn{2}{|l|}{ Recommended Hardness for these Rolls [Brinell Hardness] } \\
\cline { 2 - 3 } Hardness & on Body (Rolling Surface) of Rolls & in Core and on the Neck's of Rolls \\
\hline 0 & $218-286$ & $195-271$ \\
\hline 1 & $294-347$ & $195-271$ \\
\hline
\end{tabular}

Table 3

The Chemical Composition and the measured Hardness of the Half-hard Cast Iron Rolls

\begin{tabular}{|l|l|l|l|}
\hline Chemical Composition, $(\%)$ & Nickel [Ni] & $1.49-2.22$ \\
\hline Carbon [C] & $3.22-3.42$ & Chromium [Cr] & $0.36-0.72$ \\
\hline Silicon [Si] & $1.72-2.19$ & Molybdenum [Mo] & $0.18-0.28$ \\
\hline Manganese [Mn] & $0.62-0.79$ & Magnesium $[\mathrm{Mg}]$ & $0.021-0.029$ \\
\hline Phosphorus [P] & $0.130-0.165$ & & \\
\hline Sulphur [S] & $0.011-0.024$ & & \\
\hline Hardness, [Brinell units] & $219-276$ \\
\hline \multicolumn{2}{|l|}{ on the Necks } & $282-352$ \\
\hline on the Body &
\end{tabular}

\section{Research Methodology}

The mathematical modeling was applied, taking into consideration the industrial data obtained from the rolls industry, as well as, the cast iron roll's requirements [15] [16]. Therefore, it is suggested to use a mathematical interpretation on influence of the ductile iron's particulate elements (Phosphorus, Sulphur and Magnesium) over the hardness on the rolls rolling surface (barrel or body) and on the necks [15-24].

The performed research had in view to obtain correlations between the Half-Hard Cast Iron Rolls' Hardness and the nodular iron's permanent elements, defined by two of the main elements which have a major influence on the microstructure (i.e. Sulphur and Phosphorus), respectively by the nodulizing element (i.e. Magnesium). The performed research is structured in two specific cases, based on the different values measured on the roll's components (the two necks and the body/rolling surface) [15-24]. 
The Half-Hard Cast Iron Rolls' chemical composition and their hardness variation limits (measured on necks and on the body) are presented in Table 4. Also, the average values and the deviations of variables are presented in Table 5.

Table 4

The Half-hard cast iron rolls' chemical composition and the hardness variation limits

$$
\left([\mathrm{HB}]_{(\text {necks })}=\mathrm{f}([\mathrm{S}],[\mathrm{P}],[\mathrm{Mg}]) \text { and }[\mathrm{HB}]_{(\text {body })}=\mathrm{f}([\mathrm{S}],[\mathrm{P}],[\mathrm{Mg}])\right.
$$

\begin{tabular}{|c|c|c|c|c|c|c|c|}
\hline \multicolumn{2}{|c|}{ Sulphur $[S]$} & \multicolumn{2}{|c|}{ Phosphorus [P] } & \multicolumn{2}{|c|}{ Magnesium [Mg] } & \multicolumn{2}{|c|}{ Hardness $[\mathrm{HB}]_{(\mathrm{necks})}$} \\
\hline$[\mathrm{S}]_{\mathrm{inf}}$ & {$[\mathrm{S}]_{\text {sup }}$} & {$[\mathrm{P}]_{\mathrm{inf}}$} & {$[\mathrm{P}]_{\text {sup }}$} & {$[\mathrm{Mg}]_{\text {inf }}$} & {$[\mathrm{Mg}]_{\text {sup }}$} & {$[\mathrm{HB}]_{\mathrm{inf}}$} & {$[\mathrm{HB}]_{\mathrm{inf}}$} \\
\hline 0.011 & 0.024 & 0.128 & 0.165 & 0.021 & 0.031 & 219 & 276 \\
\hline \multicolumn{8}{|c|}{ Case 2: Modelling on data measured on the roll's body (rolling surface) } \\
\hline \multicolumn{2}{|c|}{ Sulphur $[S]$} & \multicolumn{2}{|c|}{ Phosphorus [P] } & \multicolumn{2}{|c|}{ Magnesium $[\mathrm{Mg}]$} & \multicolumn{2}{|c|}{ Hardness $[\mathrm{HB}]_{(\text {body })}$} \\
\hline$[\mathrm{S}]_{\mathrm{inf}}$ & {$[\mathrm{S}]_{\text {sup }}$} & {$[\mathrm{P}]_{\mathrm{inf}}$} & {$[\mathrm{P}]_{\text {sup }}$} & {$[\mathrm{Mg}]_{\text {inf }}$} & {$[\mathrm{Mg}]_{\text {sup }}$} & {$[\mathrm{HB}]_{\mathrm{inf}}$} & {$[\mathrm{HB}]_{\mathrm{inf}}$} \\
\hline 0.011 & 0.024 & 0.128 & 0.165 & 0.021 & 0.031 & 280 & 352 \\
\hline
\end{tabular}

Table 5

The Half-hard cast iron rolls' chemical composition and the hardness average values and deviations of variables $\left([\mathrm{HB}]_{(\text {necks })}=\mathrm{f}([\mathrm{S}],[\mathrm{P}],[\mathrm{Mg}])\right.$ and $[\mathrm{HB}]_{(\text {body })}=\mathrm{f}([\mathrm{S}],[\mathrm{P}],[\mathrm{Mg}])$

\begin{tabular}{|c|c|c|c|c|c|c|c|}
\hline \multicolumn{8}{|c|}{ Case 1: Modelling on data measured on the roll's necks } \\
\hline \multicolumn{2}{|c|}{ Sulphur [S] } & \multicolumn{2}{|c|}{ Phosphorus [P] } & \multicolumn{2}{|c|}{ Magnesium [Mg] } & \multicolumn{2}{|c|}{ Hardness $[\mathrm{HB}]_{(\text {necks })}$} \\
\hline$[\mathrm{S}]_{\mathrm{med}}$ & deviation & {$[\mathrm{P}]_{\mathrm{med}}$} & deviation & {$[\mathrm{Mg}]_{\text {med }}$} & deviation & {$[\mathrm{HB}]_{(\text {necks)med }}$} & deviation \\
\hline 0.0179 & 0.0036 & 0.1515 & 0.0107 & 0.0256 & 0.0029 & 251.52 & 13.622 \\
\hline \multicolumn{8}{|c|}{ Case 2: Modelling on data measured on the roll's body (rolling surface) } \\
\hline \multicolumn{2}{|c|}{ Sulphur [S] } & \multicolumn{2}{|c|}{ Phosphorus $[\mathrm{P}]$} & \multicolumn{2}{|c|}{ Magnesium [Mg] } & \multicolumn{2}{|c|}{ Hardness [HB] (body) } \\
\hline$[S]_{\text {med }}$ & deviation & {$[\mathrm{P}]_{\text {med }}$} & deviation & {$[\mathrm{Mg}]_{\text {med }}$} & deviation & {$[\mathrm{HB}]_{\text {(body)med }}$} & deviation \\
\hline 0.0179 & 0.0036 & 0.1515 & 0.0107 & 0.0256 & 0.0029 & 308.32 & 22.107 \\
\hline
\end{tabular}

A rigorous foundation of the existence of a correlation and the existence of a model describing the correlation between variables, also called a regression model, can be made on the basis of the calculation and interpretation of statistical indicators [15-24]. Several steps will be taken, such as:

- Check the existence of a correlation

- Establish the mathematical shape of the model

- Analysis of the empirical regression curve

- Determine the parameters that appear in the model equation

- Use the model to forecast calculations 
There are also parameters that measure the correlation (degree of association) between two qualitative variables, parameters based on the occurrence frequencies of variable values and not on values [15] [16]. Once the existence of the correlation between variables is established, we can proceed to the establishment of the regression model describing the correlation [15-24].

The mathematical modeling was applied based on the differentiation between the component parts of the rolls [15] [16] [25]. Starting from the rolling rolls' aspect, the shape of the rolls, the areas of technological interest and the structure that ensures the operational mechanical properties, it has been developed, by modeling, the mathematical description of direct influences and finally, by successive determinations, an optimum chemical composition which assures the desired rolls' hardness [15-24]. The multiple regression was used to predict the value of a variable based on the value of two or more other variables [15-24]. The study of a regression model involves the following aspects:

- Determination of regression hyper-surface, specific to multiple regression with several variables

- Determination of correlation coefficients

- Determination of deviation from the regression surface

- Determining the coordinates of the optimal points, for which there are desired values

- Determination of regression areas, specific to regression with 2 variables

- The graphic representation of the regression curve based on observed data

- Verification on the correlation graphs of the optimal range

In our statistical modelling, the regression analysis was used for estimating the relationships among the proper hardness (Hardness [HB]) and these elements (Phosphorus, Sulphur and Magnesium). To determine to what extent independent variables contribute to the modification of the dependent variable a multiple regression model was developed and will determine whether it can be considered valid, i.e. whether or not there is a correlation between a mechanical property (rolls' hardness), the level of concentrations of permanent chemical elements (Phosphorus and Sulphur) and the concentrations of elements added to the nodulizing treatment with Magnesium, characterized by certain values of independent variables. 


\section{Results of the Statistical Modeling}

Statistical modeling determines the coordinates of the optimal point $([\mathrm{S}],[\mathrm{P}],[\mathrm{Mg}])$, for which $[\mathrm{HB}]_{(\text {necks) }}$ and $[\mathrm{HB}]_{(\text {body }}$ has desired values (Table 6).

Table 6

The coordinates of the optimal point

\begin{tabular}{|l|l|l|l|}
\hline \multicolumn{4}{|l|}{ Case 1: Modelling on data measured on the roll's necks } \\
\hline$[\mathrm{S}]_{\text {statistical }}$ & {$[\mathrm{P}]_{\text {statistical }}$} & {$[\mathrm{Mg}]_{\text {statistical }}$} & {$[\mathrm{HB}]_{\text {(necks)statistical }}$} \\
\hline 0.0191 & 0.1472 & 0.0259 & 260.9375 \\
\hline \multicolumn{4}{|l|}{} \\
\hline \multicolumn{4}{|l|}{ Case 2: Modelling on data measured on the roll's body (rolling surface) } \\
\hline$[\mathrm{S}]_{\text {statistical }}$ & {$[\mathrm{P}]_{\text {statistical }}$} & {$[\mathrm{Mg}]_{\text {statistical }}$} & {$[\mathrm{HB}]_{\text {(body) statistical }}$} \\
\hline 0.0212 & 0.1562 & 0.0235 & 327.1099 \\
\hline
\end{tabular}

The correlations between the hardness of the Half-hard cast iron rolls and the defined three chemical elements are studied $\left([\mathrm{HB}]_{(\text {necks })}=\mathrm{f}([\mathrm{S}],[\mathrm{P}],[\mathrm{Mg}])\right.$ and $[\mathrm{HB}]_{(\text {body })}=\mathrm{f}([\mathrm{S}],[\mathrm{P}],[\mathrm{Mg}])$, using the values presented in Table 4. Two polynomial type of correlation was revealed, presented in the equation (1) and (2).

The proper mathematical correlation, in the case of $[\mathrm{HB}]_{(\text {necks })}=\mathrm{f}([\mathrm{S}],[\mathrm{P}],[\mathrm{Mg}])$, is given by the equation of regression hyper-surface (1), where the correlation coefficient is $\mathrm{rf}=0.6816$ and the deviation from the regression surface is $\mathrm{sf}=$ 9.9675. The proper mathematical correlation, in the case of $[\mathrm{HB}]_{(\text {body })}=\mathrm{f}([\mathrm{S}],[\mathrm{P}],[\mathrm{Mg}])$, is given by the equation of regression hyper-surface (2), where the correlation coefficient is $\mathrm{rf}=0.6841$ and the deviation from the regression surface is $\mathrm{sf}=16.1240$.

$$
\begin{gathered}
{[\mathrm{HB}]_{(\text {necks) }}=-1729.1599[\mathrm{~S}]^{2}-33258.1844[\mathrm{P}]^{2}-14187.7104[\mathrm{Mg}]^{2}} \\
-72143.1146[\mathrm{~S}][\mathrm{P}]-34036.2106[\mathrm{P}][\mathrm{Mg}]-10818.3003[\mathrm{Mg}][\mathrm{S}]+ \\
45269.1696[\mathrm{~S}]+12044.2871[\mathrm{P}]+33001.3626[\mathrm{Mg}]-1484.7255 \\
{[\mathrm{HB}]_{(\text {body })}=-5523.0405[\mathrm{~S}]^{2}-44607.2162[\mathrm{P}]^{2}-6146.3995[\mathrm{Mg}]^{2}+} \\
14432.6465[\mathrm{~S}][\mathrm{P}]-41587.5438[\mathrm{P}][\mathrm{Mg}]-13741.9865[\mathrm{Mg}][\mathrm{S}]+ \\
53316.7961[\mathrm{~S}]+14603.5068[\mathrm{P}]+64322.9104[\mathrm{Mg}]-2130.4001
\end{gathered}
$$

Since this hyper-surface cannot be represented in the $4^{\text {th }}$ dimensional space, I resorted to replacing, successively, an independent variable [15] [16]. In order to determine the limits of graphic representation, it is used to replace, successively, a variable independent with the values of the limits of the chemical composition, presented above in Table 4 . These surfaces in the $3^{\text {rd }}$ dimensional space are governed by the eq. (1.1) - (1.6), respectively equations $(2.1)-(2.6)$.

$$
\begin{gathered}
{[\mathrm{HB}]_{(\text {necks) }}[\mathrm{S}]_{\text {inf }}=-33258.1844[\mathrm{P}]^{2}-14187.7104[\mathrm{Mg}]^{2}-34036.2106} \\
{[\mathrm{P}][\mathrm{Mg}]+10625.1483[\mathrm{P}]+11721.3703[\mathrm{Mg}]-661.1456} \\
{[\mathrm{HB}]_{(\text {necks) }}[\mathrm{S}]_{\text {sup }}=-33258.1844[\mathrm{P}]^{2}-14187.7104[\mathrm{Mg}]^{2}-34036.2106} \\
{[\mathrm{P}][\mathrm{Mg}]+10885.0937[\mathrm{P}]+15619.2532[\mathrm{Mg}]-801.9896}
\end{gathered}
$$


$[\mathrm{HB}]_{(\mathrm{necks})}[\mathrm{P}]_{\mathrm{inf}}=-14187.7104[\mathrm{Mg}]^{2}-1729.1599[\mathrm{~S}]^{2}-10818.3003$ $[\mathrm{Mg}][\mathrm{S}]+27663.5758[\mathrm{Mg}]+33955.2026[\mathrm{~S}]-413.8319$

$[\mathrm{HB}]_{(\mathrm{necks})}[\mathrm{P}]_{\text {sup }}=-14187.7104[\mathrm{Mg}]^{2}-1729.1599[\mathrm{~S}]^{2}-10818.3003$

$[\mathrm{Mg}][\mathrm{S}]+28027.6574[\mathrm{Mg}]+34726.9095[\mathrm{~S}]-434.8887$

$[\mathrm{HB}]_{(\text {necks })}[\mathrm{Mg}]_{\text {inf }}=-1729.1599[\mathrm{~S}]^{2}-33258.1844[\mathrm{P}]^{2}-72143.1146$ $[\mathrm{S}][\mathrm{P}]+16011.4863[\mathrm{~S}]+11123.7535[\mathrm{P}]-695.9543$

$[\mathrm{HB}]_{(\text {necks })}[\mathrm{Mg}]_{\text {sup }}=-1729.1599[\mathrm{~S}]^{2}-33258.1844[\mathrm{P}]^{2}-72143.1146$

$[\mathrm{S}][\mathrm{P}]+19214.6491[\mathrm{~S}]+11224.5345[\mathrm{P}]-772.1924$

$[\mathrm{HB}]_{(\text {body })}[\mathrm{S}]_{\text {med }}=-44607.2162[\mathrm{P}]^{2}-6146.3995[\mathrm{Mg}]^{2}-41587.5438$ $[\mathrm{P}][\mathrm{Mg}]+14887.4137[\mathrm{P}]+37291.7653[\mathrm{Mg}]-1295.3177$

$[\mathrm{HB}]_{(\text {body })}[\mathrm{S}]_{\mathrm{med}}=-44607.2162[\mathrm{P}]^{2}-6146.3995[\mathrm{Mg}]^{2}-41587.5438$ $[\mathrm{P}][\mathrm{Mg}]+14835.4102[\mathrm{P}]+42243.0941[\mathrm{Mg}]-1416.3042$

$\mathrm{HB}]_{(\text {body })}[\mathrm{P}]_{\text {med }}=-6146.3995[\mathrm{Mg}]^{2}-5523.0405[\mathrm{~S}]^{2}-13741.9865$

$[\mathrm{Mg}][\mathrm{S}]+57800.8729[\mathrm{Mg}]+55580.2205[\mathrm{~S}]-937.2776$

$[\mathrm{HB}]_{(\text {body })}[\mathrm{P}]_{\text {med }}=-6146.3995[\mathrm{Mg}]^{2}-5523.0405[\mathrm{~S}]^{2}-13741.9865$

$[\mathrm{Mg}][\mathrm{S}]+58245.7302[\mathrm{Mg}]+55425.8361[\mathrm{~S}]-948.9314$

$[\mathrm{HB}]_{(\text {body })}[\mathrm{Mg}]_{\text {med }}=-5523.0405[\mathrm{~S}]^{2}-44607.2162[\mathrm{P}]^{2}+14432.6465$

$[\mathrm{S}][\mathrm{P}]+16151.9009[\mathrm{~S}]+13478.7422[\mathrm{P}]-840.3223$

$[\mathrm{HB}]_{(\text {body })}[\mathrm{Mg}]_{\text {med }}=-5523.0405[\mathrm{~S}]^{2}-44607.2162[\mathrm{P}]^{2}+14432.6465$

$[\mathrm{S}][\mathrm{P}]+20220.7538[\mathrm{~S}]+13601.8825[\mathrm{P}]-937.7295$

In the equation of hyper-surfaces (1) and (2), it is used to replace, successively, a variable independent with its mean value. These surfaces, which belong to the whole space with $3^{\text {rd }}$ dimensions, can be represented and interpreted by technologists. Therefore, the independent variables were successively replaced with their average values (i.e. [S]med, [P]med and [Mg]med, Table 5).

A polynomial type of correlations was revealed, which have the following general forms, presented in the equations (1.7) - (1.9), respectively (2.7) - (2.9).

$$
\begin{gathered}
{[\mathrm{HB}]_{(\text {necks })}[\mathrm{S}]_{\text {med }}=-33258.1844[\mathrm{P}]^{2}-14187.7104[\mathrm{Mg}]^{2}-34036.2106} \\
{[\mathrm{P}][\mathrm{Mg}]+10755.1212[\mathrm{P}]+13670.3117[\mathrm{Mg}]-731.0063} \\
{[\mathrm{HB}]_{(\text {necks) }}[\mathrm{P}]_{\text {med }}=-14187.7104[\mathrm{Mg}]^{2}-1729.1599[\mathrm{~S}]^{2}-10818.3003} \\
{[\mathrm{Mg}][\mathrm{S}]+27845.6166[\mathrm{Mg}]+34341.0561[\mathrm{~S}]-423.4089} \\
{[\mathrm{HB}]_{(\text {necks) }}[\mathrm{Mg}]_{\text {med }}=-1729.1599[\mathrm{~S}]^{2}-33258.1844[\mathrm{P}]^{2}-72143.1146} \\
{[\mathrm{~S}][\mathrm{P}]+17613.0677[\mathrm{~S}]+11174.1442[\mathrm{P}]-733.7624} \\
{[\mathrm{HB}]_{(\text {body }}[\mathrm{S}]_{\text {med }}=-44607.2162[\mathrm{P}]^{2}-6146.3995[\mathrm{Mg}]^{2}-41587.5438} \\
{[\mathrm{P}][\mathrm{Mg}]+14861.4122[\mathrm{P}]+39767.4297[\mathrm{Mg}]-1354.0182}
\end{gathered}
$$




$$
\begin{gathered}
{[\mathrm{HB}]_{(\text {body })}[\mathrm{P}]_{\text {med }}=-6146.3995[\mathrm{Mg}]^{2}-5523.0405[\mathrm{~S}]^{2}-13741.9865} \\
{[\mathrm{Mg}][\mathrm{S}]+58023.3016[\mathrm{Mg}]+55503.0283[\mathrm{~S}]-941.8285} \\
{[\mathrm{HB}]_{(\text {body })}[\mathrm{Mg}]_{\text {med }}=-5523.0405[\mathrm{~S}]^{2}-44607.2162[\mathrm{P}]^{2}+14432.6465} \\
{[\mathrm{~S}][\mathrm{P}]+18186.3274[\mathrm{~S}]+13540.3122[\mathrm{P}]-887.6787}
\end{gathered}
$$

\section{Graphical Addenda}

The $3^{\text {th }}$ dimensional regression surfaces, described by the governing equations $(1.1)-(1.6)$ and $(2.1)-(2.6)$, respectively, are represented graphically in Figure 6 , case of $\left.[\mathrm{HB}]_{(\text {necks })}=\mathrm{f}([\mathrm{S}],[\mathrm{P}],[\mathrm{Mg}])\right)$ and Figure 7 , case of $\left.[\mathrm{HB}]_{(\text {body })}=\mathrm{f}([\mathrm{S}],[\mathrm{P}],[\mathrm{Mg}])\right)$.

(a)
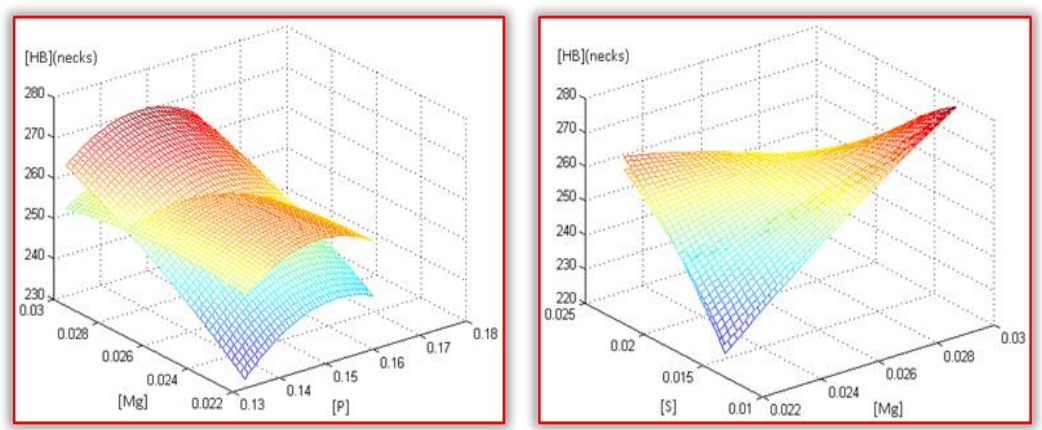

(b)

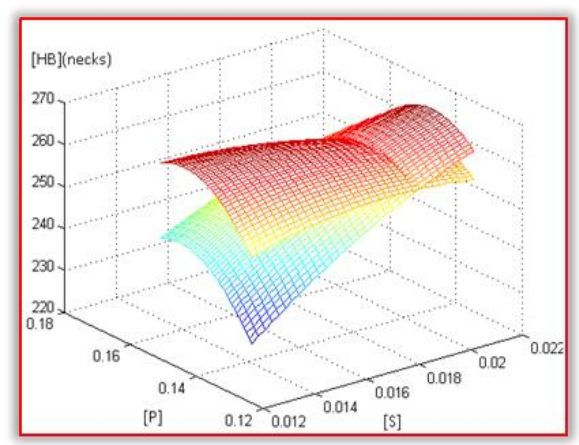

(c)

Figure 6

Regression surfaces in case of $[\mathrm{HB}]_{(\text {necks) }}=\mathrm{f}([\mathrm{S}],[\mathrm{P}],[\mathrm{Mg}])$, according to the equations (1.1)-(1.6). (a) the regression surface described by the industrial data, when $[S]=[S]$ inf and $[S]=[S] \sup$; (b) the regression surface described by the industrial data, when $[\mathrm{P}]=[\mathrm{P}]$ inf and $[\mathrm{P}]=[\mathrm{P}] \sup$; (c) the regression surface described by the industrial data, when $[\mathrm{Mg}]=[\mathrm{Mg}]$ inf and $[\mathrm{Mg}]=[\mathrm{Mg}] \sup$ 
The regression surfaces, described by the eq. (1.1) - (1.9), respectively eq. (2.1) (2.9), are presented in Figures 8-10 and Figures 11-13. The correlation charts and the contour lines which define the requested limits of the proper hardness, in cases of $[\mathrm{HB}]_{(\text {necks })}=\mathrm{f}([\mathrm{S}],[\mathrm{P}],[\mathrm{Mg}])$ and $[\mathrm{HB}]_{(\text {necks })}=\mathrm{f}([\mathrm{S}],[\mathrm{P}],[\mathrm{Mg}])$ are presented in the Figures 14-19.

In this sense, the rolls' hardness variations on the necks and core, described by these elements, are presented in Figures 14-16, determined by Matlab, using the polynomial equations presented in the eq. (1.7), (1.8) and (1.9). The rolls' hardness variations on the body, are presented in Figures 17-19, using the polynomial equations presented in the equations (2.7), (2.8) and (2.9).

(a)
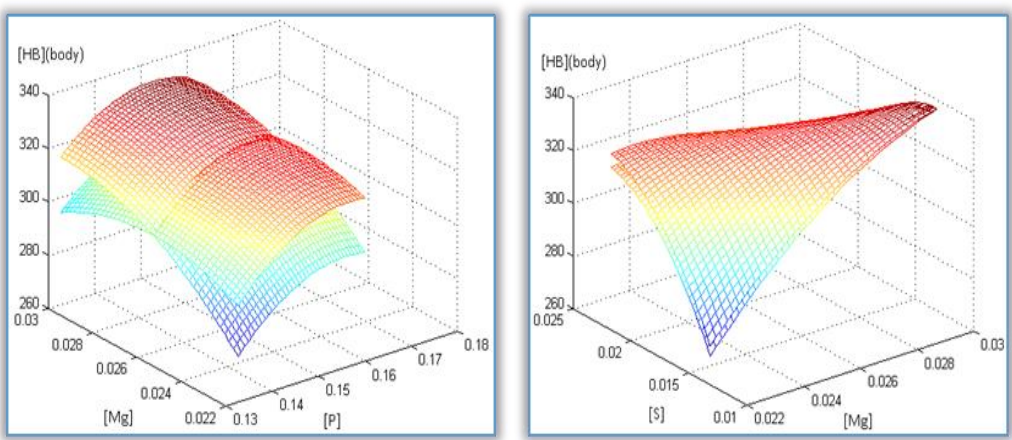

(b)

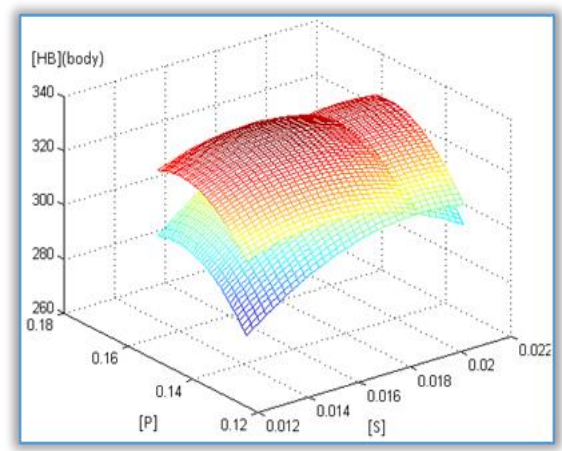

(c)

Figure 7

Regression surfaces in case of $[\mathrm{HB}]_{(\text {body })}=\mathrm{f}([\mathrm{S}],[\mathrm{P}],[\mathrm{Mg}])$, according to the equations (2.1)-(2.6)

(a) the regression surface described by the industrial data, when $[\mathrm{S}]=[\mathrm{S}] \mathrm{inf}$ and $[\mathrm{S}]=[\mathrm{S}]$ sup;

(b) the regression surface described by the industrial data, when $[\mathrm{P}]=[\mathrm{P}]$ inf and $[\mathrm{P}]=[\mathrm{P}]$ sup;

(c) the regression surface described by the industrial data, when $[\mathrm{Mg}]=[\mathrm{Mg}] \inf$ and $[\mathrm{Mg}]=[\mathrm{Mg}] \sup$ 
(a)
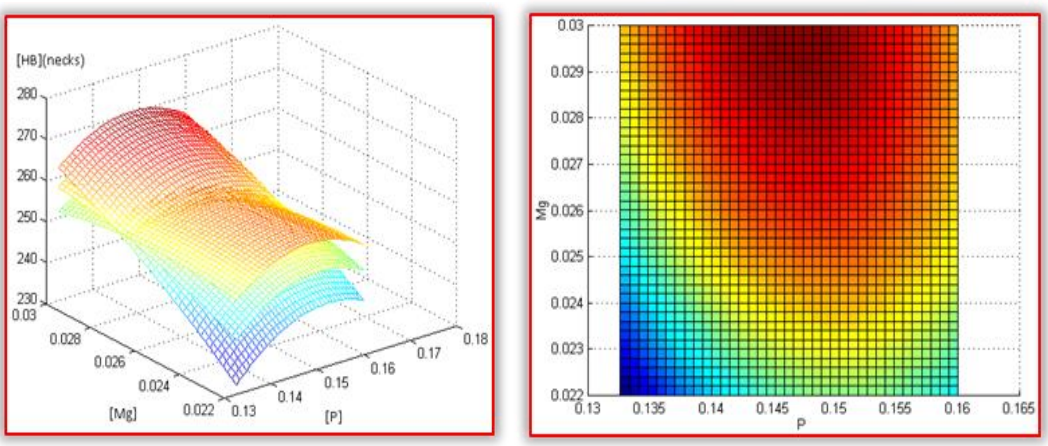

(b)

Figure 8

Regression surfaces in case of $[\mathrm{HB}]_{(\mathrm{body})}=\mathrm{f}([\mathrm{S}],[\mathrm{P}],[\mathrm{Mg}])$, according to the equation (1.7)

(a) the regression surfaces; (b) color mapping of the technological areas

(a)
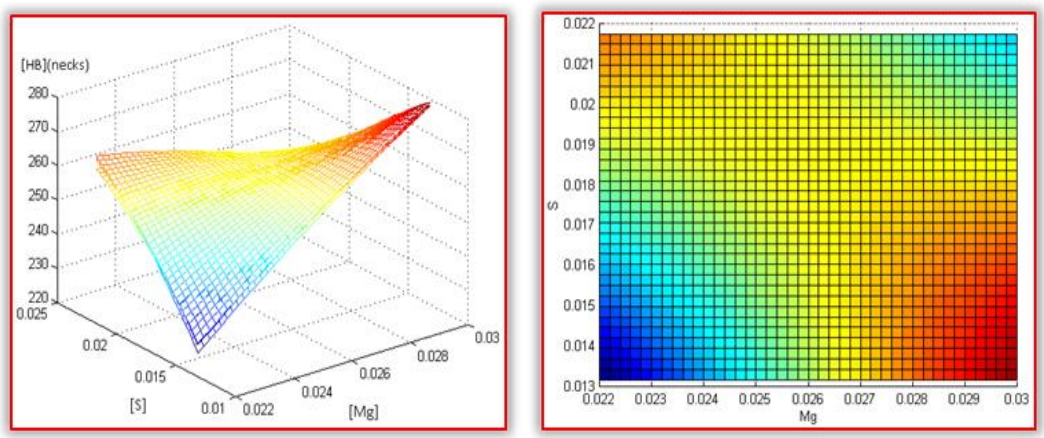

(b)

Figure 9

Regression surfaces in case of $[\mathrm{HB}]_{(\mathrm{body})}=\mathrm{f}([\mathrm{S}],[\mathrm{P}],[\mathrm{Mg}])$, according to the equation (1.8)

(a) the regression surfaces; (b) color mapping of the technological areas
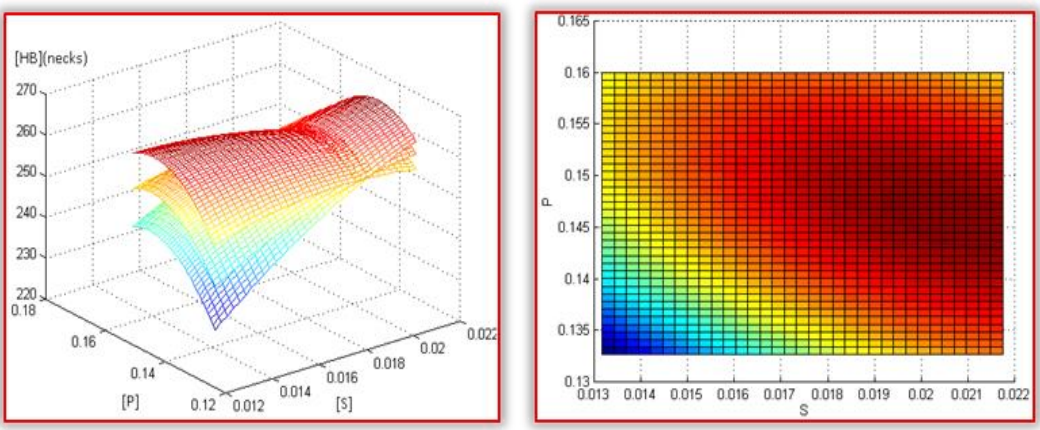

(b)

Figure 10

Regression surfaces in case of $[\mathrm{HB}]_{(\text {body })}=\mathrm{f}([\mathrm{S}],[\mathrm{P}],[\mathrm{Mg}])$, according to the equation (1.7)

(a) the regression surfaces; (b) color mapping of the technological areas 
(a)
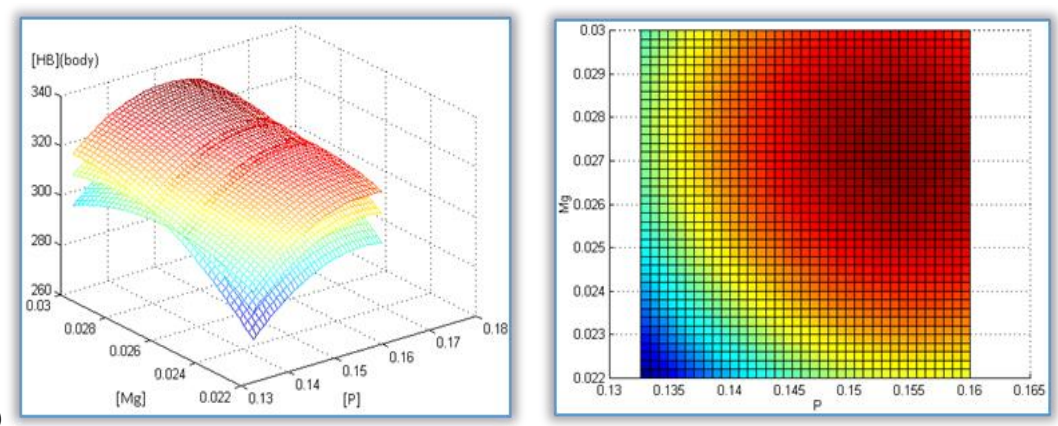

(b)

Figure 11

Regression surfaces in case of $[\mathrm{HB}]_{(\text {necks })}=\mathrm{f}([\mathrm{S}],[\mathrm{P}],[\mathrm{Mg}])$, according to the equation $(2.7)$

(a) the regression surfaces; (b) color mapping of the technological areas

(a)
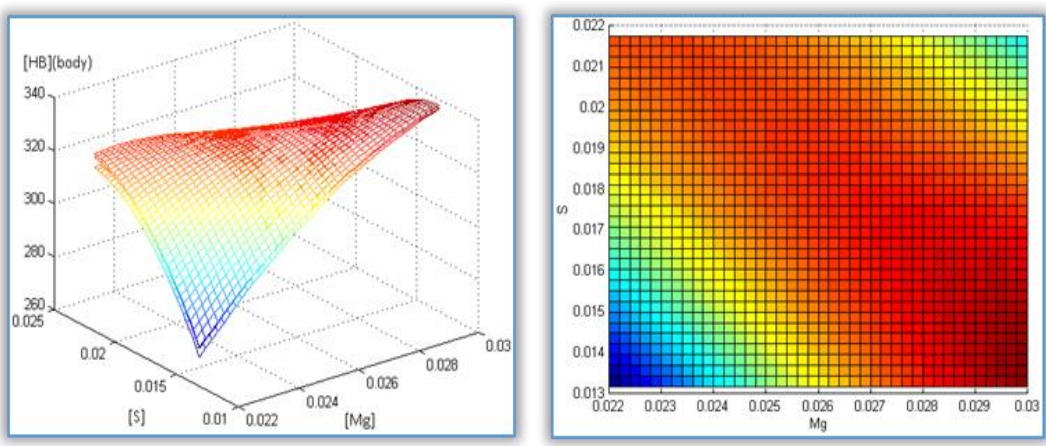

(b)

Figure 12

Regression surfaces in case of $[\mathrm{HB}]_{(\text {necks })}=\mathrm{f}([\mathrm{S}],[\mathrm{P}],[\mathrm{Mg}])$, according to the equation (2.8)

(a) the regression surfaces; (b) color mapping of the technological areas
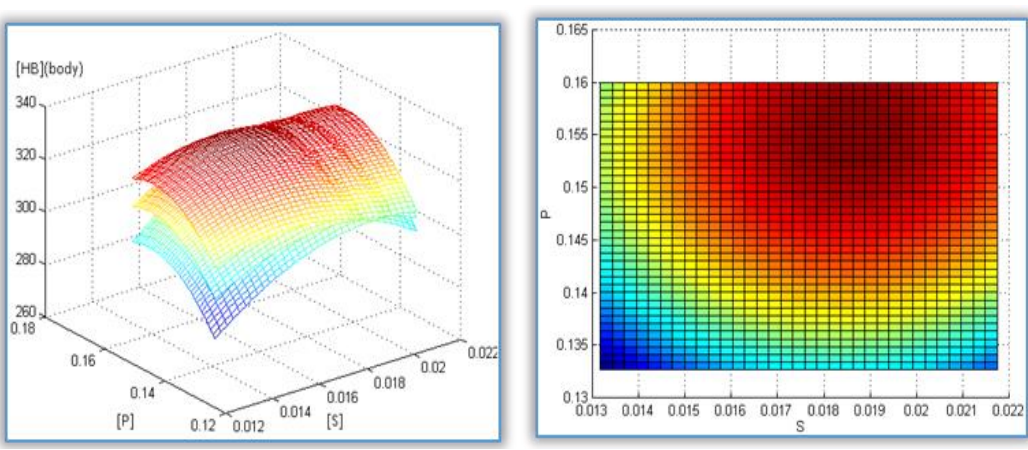

Figure 13

Regression surfaces in case of $[\mathrm{HB}]_{(\text {necks) }}=\mathrm{f}([\mathrm{S}],[\mathrm{P}],[\mathrm{Mg}])$, according to the equation (2.9)

(a) the regression surfaces; (b) color mapping of the technological areas 
(a)
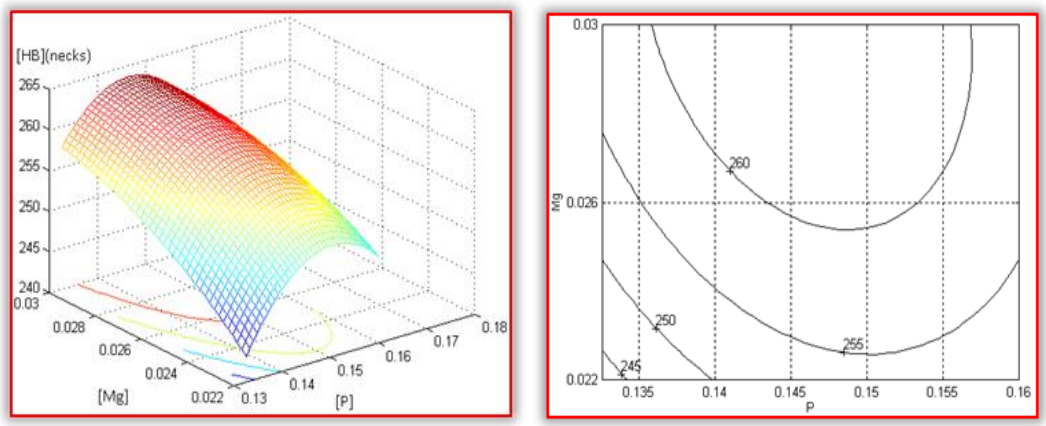

(b)

Figure 14

Correlation charts in case of $[\mathrm{HB}]_{(\text {necks) }}=\mathrm{f}([\mathrm{S}],[\mathrm{P}],[\mathrm{Mg}])$, when $[\mathrm{S}]=[\mathrm{S}] \mathrm{med}$. (a) regression surface for $[\mathrm{HB}]_{(\text {necks) }}=[\mathrm{HB}]_{(\text {necks) }}\left([\mathrm{S}],[\mathrm{P}],[\mathrm{Mg}]_{\mathrm{med}}\right) ;\left(\right.$ b) contour lines for $[\mathrm{HB}]_{(\text {necks })}=[\mathrm{HB}]_{(\text {necks })}\left([\mathrm{S}]_{\text {med }},[\mathrm{P}],[\mathrm{Mg}]\right)$

(a)
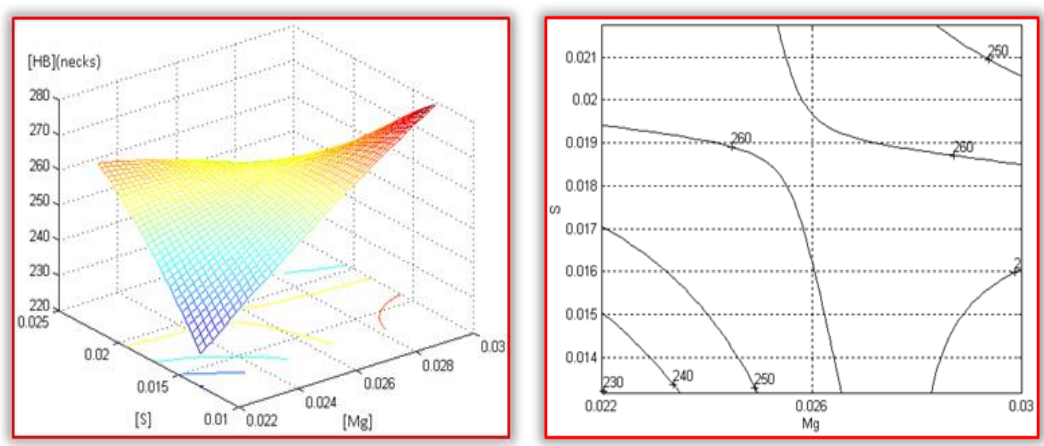

(b)

Figure 15

Correlation charts in case of $[\mathrm{HB}]_{(\text {necks) }}=\mathrm{f}([\mathrm{S}],[\mathrm{P}],[\mathrm{Mg}])$, when $[\mathrm{P}]=[\mathrm{P}]$ med. (a) regression surface for

$[\mathrm{HB}]_{(\text {necks })}=[\mathrm{HB}]_{(\text {necks) }}\left([\mathrm{S}],[\mathrm{P}],[\mathrm{Mg}]_{\mathrm{med}}\right)(\mathrm{b})$ contour lines for $[\mathrm{HB}]_{(\text {necks) }}=[\mathrm{HB}]_{(\text {necks) }}\left([\mathrm{S}],[\mathrm{P}]_{\text {med }},[\mathrm{Mg}]\right)$

(a)
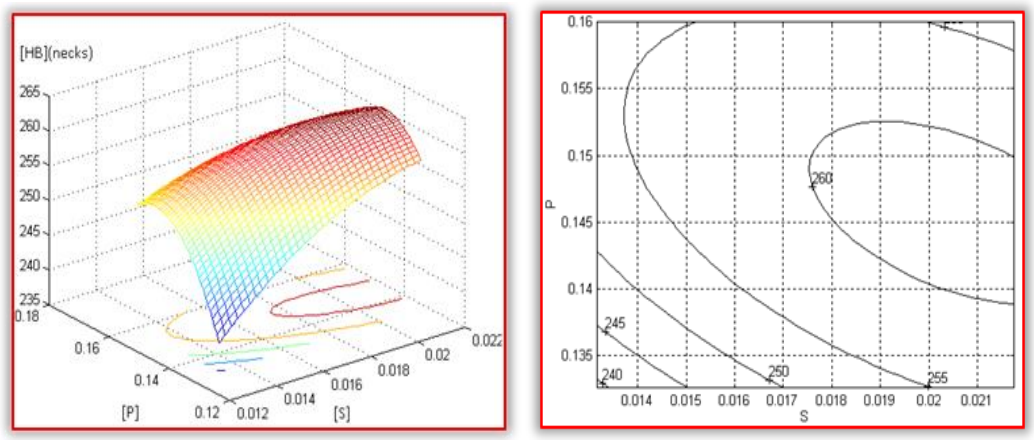

(b)

Figure 16

Correlation charts in case of $[\mathrm{HB}]_{(\text {necks })}=\mathrm{f}([\mathrm{S}],[\mathrm{P}],[\mathrm{Mg}])$, when $[\mathrm{Mg}]=[\mathrm{Mg}]$ med. (a) regression surface for $[\mathrm{HB}]_{(\text {necks })}=[\mathrm{HB}]_{(\text {necks })}\left([\mathrm{S}],[\mathrm{P}],[\mathrm{Mg}]_{\mathrm{med}}\right) ;(\mathrm{b})$ contour lines for $[\mathrm{HB}]_{(\text {necks })}=[\mathrm{HB}]_{(\text {necks })}\left([\mathrm{S}],[\mathrm{P}],[\mathrm{Mg}]_{\text {med }}\right)$ 
(a)
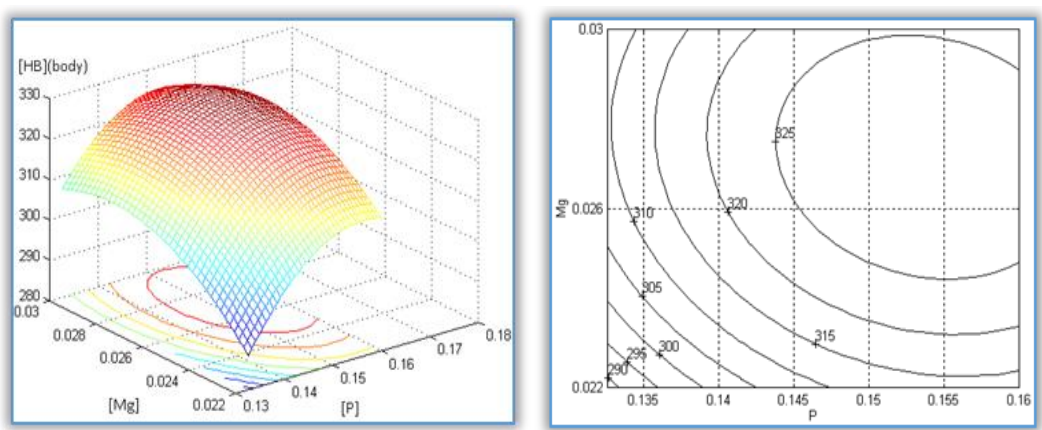

(b)

Figure 17

Correlation charts in case of $[\mathrm{HB}]_{(\text {necks })}=\mathrm{f}([\mathrm{S}],[\mathrm{P}],[\mathrm{Mg}])$, when $[\mathrm{S}]=[\mathrm{S}]$ med. (a) regression surface for $[\mathrm{HB}]_{(\mathrm{necks})}=[\mathrm{HB}]_{(\mathrm{necks})}\left([\mathrm{S}],[\mathrm{P}],[\mathrm{Mg}]_{\mathrm{med}}\right) ;\left(\right.$ b) contour lines for $[\mathrm{HB}]_{(\text {necks })}=[\mathrm{HB}]_{(\text {necks })}\left([\mathrm{S}]_{\text {med }},[\mathrm{P}],[\mathrm{Mg}]\right)$

(a)
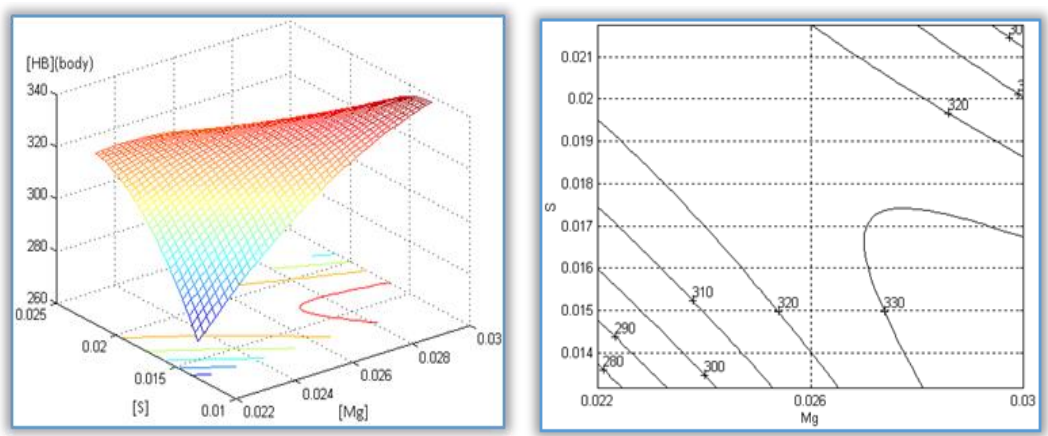

(b)

Figure 18

Correlation charts in case of $[\mathrm{HB}]_{(\text {necks })}=\mathrm{f}([\mathrm{S}],[\mathrm{P}],[\mathrm{Mg}])$, when $[\mathrm{P}]=[\mathrm{P}]$ med. (a) regression surface for $[\mathrm{HB}]_{(\text {necks) }}=[\mathrm{HB}]_{(\text {necks) }}\left([\mathrm{S}],[\mathrm{P}],[\mathrm{Mg}]_{\mathrm{med}}\right) ;\left(\right.$ b) contour lines for $[\mathrm{HB}]_{(\text {necks })}=[\mathrm{HB}]_{(\text {necks })}\left([\mathrm{S}],[\mathrm{P}]_{\text {med }},[\mathrm{Mg}]\right)$

(a)
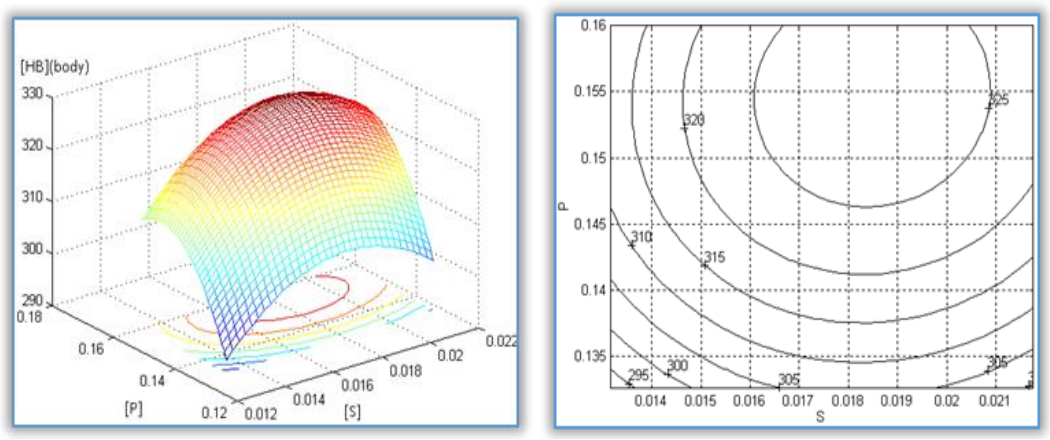

(b)

Figure 19

Correlation charts in case of $[\mathrm{HB}]_{(\text {necks })}=\mathrm{f}([\mathrm{S}],[\mathrm{P}],[\mathrm{Mg}])$, when $[\mathrm{Mg}]=[\mathrm{Mg}] \mathrm{med}$. (a) regression surface for $[\mathrm{HB}]_{(\text {necks })}=[\mathrm{HB}]_{(\text {necks })}\left([\mathrm{S}],[\mathrm{P}],[\mathrm{Mg}]_{\mathrm{med}}\right) ;\left(\right.$ b) contour lines for $[\mathrm{HB}]_{(\text {necks })}=[\mathrm{HB}]_{(\text {necks) }}\left([\mathrm{S}],[\mathrm{P}],[\mathrm{Mg}]_{\mathrm{med}}\right)$ 


\section{Discussion}

Regarding the multiple regression analysis, in order to understand the relationships between the variables and their relevance to the problem being studied, are the following remarks:

- The problem of regression starts from the existence of a data set on two or more random variables, the purpose of modeling being the description of the relationship between them, i.e. determining function $f$, in order to forecast the values of the dependent variable in relation to the values of the explanatory variables. This problem arises only when there is a real link between the variables, based on the nature of the underlying phenomena.

- The coefficient shows the role played by all exogenous (dependent) variables on the evolution of the endogenous variable (independent). The correlation coefficient is interpreted as follows: a high value, close to 1 , indicating a good adjustment of the data, while a value close to 0 , indicates a weak adjustment. In both cases $\left([\mathrm{HB}]_{(\text {necks })}=\mathrm{f}([\mathrm{S}],[\mathrm{P}],[\mathrm{Mg}])\right)$ and $[\mathrm{HB}]_{(\text {body })}=\mathrm{f}$ $([\mathrm{S}],[\mathrm{P}],[\mathrm{Mg}])$ ), the values of the correlation coefficient $(\mathrm{rf}=0.6816$, respectively $\mathrm{rf}=0.6841$ ) indicate a fairly good correlation between the studied variables.

- The used model of regression belongs to the category of stochastic (statistical) models, in which all the explanatory factors of a phenomenon, which do not find their place directly in the model, appear accumulated in the form of a random variable called error. A variable (an output parameter) that quantifies the studied phenomenon can be explained by regression on one or more explanatory factors (input parameters). All explanatory factors that are not sufficiently relevant to the output parameter enter into the model in the cumulative form of the error. In this model, the residues (errors) do not behave randomly and are quite large.

- The technological domain area of proper hardness is presented in Figures 1416, respectively in Figures 17-19. The relationships that determine the technological areas are useful because they can indicate a predictive relationship that can be exploited in practice.

In summary, the recent study of a regression model $\left([\mathrm{HB}]_{(\text {necks })}=\mathrm{f}([\mathrm{S}],[\mathrm{P}],[\mathrm{Mg}])\right.$ and $[\mathrm{HB}]_{(\mathrm{body})}=\mathrm{f}([\mathrm{S}],[\mathrm{P}],[\mathrm{Mg}])$ involves the following aspects:

- Establish the analytical limits, defined statistically

- Determining the mean value and deviations of the variables from the mean values

- Determination the regression hyper-surface's equations, correlation coefficients and regression surface deviations, resulting the eq. (1) and (2)

- Establishing the optimum value coordinates, for which the hardness has desired (optimal) values 
- Establishing the regression surface's equations, on the path of successive imposition of limit values and value chemical composition, resulting the eq. (1.1-1.9) and (2.1-2.9)

- Representation the regression surfaces, presented as rich graphical addenda, in section 5 (Figures 6-13)

- Determination the correlation charts and the level curves (contour lines) and mapping the technological areas, presented in Figures 14-16 and in Figures 17-19

- Validate the statistically determined optimal domain in the correlation charts, in which it must be found, and in our case are found, the values determined statistically and presented in Table 6 .

Having in view the complex melting process of the ductile irons destined to the half-hard cast iron rolls manufacturing, followed by a proper nodulizing process of these irons in the ladle treatment, I have the following technological remarks:

- As presented in the previous works [15-24], the chemical composition is a very important factor in the assurance of mechanical properties, especially the hardness, of these important iron products (i.e. rolls), parts of the rolling equipment. In this sense, it was declared constantly, that one of the basic factors that determine the rolls' structure is the chemical composition. Between these elements, these research show that the permanent elements like Phosphorus and Sulphur and the nodulizing agent content like Magnesium have an important technological role in assurance of these exploitation properties.

- Therefore, the desired properties of the rolls can be assured besides a proper content in Phosphorus and Sulphur, in the charging and melting process, respectively in Magnesium, in the ladle process stage, having in view the behaviour of these elements. In this sense, a proper addition of the Phosphorus and Sulphur contents are provided by the basic metallic charges used in the melting process, having in view the technological prescriptions in low Phosphorus and Sulphur content of the ductile irons. Also, important is the assuring the graphite spheres or nodules (in quantity and as form) in the as-cast condition, by adding Magnesium, which will improve the quality of these cast irons, offering an increased hardness of the rolls.

\section{Concluding Remarks}

The improved properties obtained with high-purity raw materials in making ductile iron should stimulate further investigations particularly related to obtaining the desired properties of cast products, such the rolling rolls. The mechanical properties of iron are not only determined by composition but also greatly influenced by foundry practice, particularly cooling rate in the casting. With the exception of Magnesium or other nodularizing elements in nodular iron, it is possible through variations in melting and foundry practice to produce different 
properties from the same composition. These properties are produced by increasing the alloy content mainly Nickel, Molybdenumand Chromiummodifying the matrix structure [15-24]. But, with a high percentage of graphite nodules present in the structure, the mechanical properties are determined by the ductile iron matrix. Hardness values, usually offered as additional information, and impact properties, specified only for certain grades, complete most specifications.

Based on the results obtained in the performed statistical research, it is concluded that prediction of the exploitation properties of rolls, based on the melting process and the additional "in-ladle" treatment, is a prerequisite for the cast iron roll's manufacturing. The statistical modelling by multivariate regression analysis can be used successfully to optimize the chemical composition of irons destined to rolls manufacturing. In this way, this method is very helpful to predict the cast roll's performance.

Therefore, the chemical composition of cast iron is a key-factor that largely determines mechanical properties the resulting rolls. By close control of analysis of the melting process and the additional nodulizing and inoculation practices, nodular irons can be produced in the as-cast condition over a wide range of section thicknesses with any required matrix structure from fully ferritic to fully pearlitic.

These rolls are produced in wide range of composition to satisfy the rolling mills requirement, nodular irons being much less section sensitive than grey irons. Phosphorus and Sulphur content should be as low as possible. Sulphur forms with Magnesium compounds and thus contributes to the increase of the consumption of nodulizing agent, using it inappropriately and unnecessarily. An increase in the concentration of Phosphorus in the composition causes the appearance of cracks when the composition is cooled. In addition, this element causes damage to other mechanical properties. Also, many properties are influenced by the mechanisms of primary and secondary crystallization. Ductile irons determine their properties by ferritic or pearlitic bases with the presence of nodular graphite inclusions, most of them being primary or secondary products of treatment with Magnesium.

In the complete understanding of technological reality it is often necessary to know and understand the existing correlations between two or more phenomena, quantified by different variables. For example, in order to apply a correct quality strategy on milling rolls, it is necessary to know whether there is a correlation between the acquired properties of the rolls and the main factors which influenced their manufacture.

\section{Acknowledgement}

The research includes own studies, analyses and research, regarding the quality improvement by modeling of the statistical data from the half-hard cast iron rolls used in the steel rolling. At the fundament of this statistical research upon the cast iron rolls are several relevant scientific studies [15] [16] and approaches [17-24] in which the author is involved in the last 25 years. 


\section{References}

[1] N. S. Tiedje, Solidification, processing and properties of ductile cast iron, Materials Science and Technology, 26/5 (2010), pp. 505-514

[2] J. Lacaze, Trace elements and graphite shape degeneracy in nodular graphite cast irons, International Journal of Metalcasting, 11/1 (2017), pp 44-51

[3] T. Skaland, Production of ductile cast iron from high purity charge materials, Scandinavian Journal of Metallurgy, 21/2 (1992), pp. 63-67

[4] I. Ripoşan, M. Chişamera, S. Stan, G. Grasmo, C. Hartung, D. White, Iron quality control during melting in coreless induction furance, AFS Transactions, 117 (2009), pp. 423-434

[5] O. M. Suarez, R. D. Kendrick, C. R. Loper, A study of sulphur effect in high silicon ductile irons, International Journal of Cast Metals Research, 13/3 (2000), pp. 135-145

[6] M. Chisamera, I. Riposan, M. Barstow, Sulphur inoculation of Mg-treated cast iron - An efficient possibility to obtain compacted graphite cast iron and to improve graphite nucleation ability in ductile iron, AFS Transactions, 104 (1996) pp. 581-588

[7] A. Oyetunji, S. O. Omole, Achievement of nodules in ductile iron having sulphur content not less than $0.07 \%$ weight, Annals of the Faculty of Engineering Hunedoara, 12/4 (2014) 42-46

[8] K. Janerka, J. Jezierski, D. Bartocha, J. Szajnar, Analysis of ductile iron production on steel scrap base, International Journal of Cast Metals Research, 27/4 (2014) pp. 230-234

[9] W. H. Betts, H. L. Baxter, Rolls used in today's rolling mills, Iron and Steelmaker, 18/2 (1991) pp. 42-43

[10] S. Spuzic, K. N. Strafford, C. Subramanian, G. Savage, Wear of hot rolling mill rolls: an overview, Wear, 176/2 (1994) pp. 261-271

[11] Z. Stradomski, A. Pirek, S. Stachura, Studying possibilities to improve the functional properties of metallurgical rolls, 8/1 (2008) pp. 313-316

[12] E. Kerr, R. Webber, D. McCaw, Roll performance-technical overview and future outlook, Ironmaking \& steelmaking, 31/4 (2004) pp. 295-299

[13] J. Krawczyk, J. Pacyna, Influence of a matrix on properties of mottled cast iron applied for mill rolls, Archives of Foundry Engineering, 10/3 (2010) pp. $45-50$

[14] J. Krawczyk, Structural causes of defects in a cast iron mill roll, Archives of Foundry Engineering, 8/2 (2008) pp. 93-98 
[15] I. Kiss, The quality of rolling mills rolls cast by irin with nodular graphite, Mirton Publishing House, Timisoara, 2005

[16] I. Kiss, Rolling rolls - Approaches of quality in the multidisciplinary research, Mirton Publishing House, Timisoara, 2008

[17] I. Kiss, St. Maksay, Graphical addenda in the technological area of the nodular iron cast rolls production, Acta Polytechnica Hungarica, 5/4 (2008) pp. $15-27$

[18] I. Kiss, Multivariate statistical research in areas of the cast hyper-eutectoid steel roll manufacturing, in the melting and alloying processing stages, Acta Polytechnica Hungarica, 17/6 (2020) pp. 41-59

[19] I. Kiss, Research upon the quality assurance of the rolling-mill rolls and the variation boundaries of the chemical composition, Revista de Metalurgia, 44/4 (2008) pp. 335-342

[20] I. Kiss, T. Heput, V. G. Cioata, Some interpretative research in the area of cast iron rolls quality assurance, Acta Metalurgica Slovaca, 16/1 (2010) pp 26-33

[21] I. Kiss, Cast Iron Rolls - An overview on the proper hardness assured by the manufacturing process, Tehnički glasnik-Technical Journal, 13/2 (2019) pp. $92-99$

[22] I. Kiss, V. Alexa, The multivariate analysis in area of cast irons with nodular graphite, used in the rolling rolls manufacturing, Machine Design, 4/1 (2012) pp. 43-48

[23] I. Kiss, Focus on quality assurance in the rolls manufacturing-approaches for increasing the rolling-mill rolls qualities, Acta Technica CorviniensisBulletin of Engineering, 5/2 (2012) pp. 123-128

[24] I. Kiss, V. Alexa, V. G. Cioată, S. Ratiu, Half-hard cast-iron rolls: statistically research on the manufacturing technology for increase their quality and safety in exploitation, Journal of Physics: IOP Publishing Conference Series, 1781/1 (2021) p. 012054

[25] STAS 9432-85: Rolling mills. Half-hard cast iron rolls specification 